\title{
Tobacco-alcohol optic neuropathy following festive binge drinking
}

Ng Tuck Chun, Ng Wei Loon

Department of Ophthalmology, Miri General Hospital, Sarawak, Malaysia

\section{Abstract}

This case report aims to discuss a case of tobacco-alcohol optic neuropathy secondary to alcohol abuse and chronic cigarette smoking in a 43-year-old man. Possible causes including vitamin B12 deficiency, methanol poisoning, and cyanide in tobacco were discussed. Clinical examination and blood investigation supported the diagnosis of vitamin B12 deficiency, possibly precipitated by methanol and cyanide. The patient was treated with vitamin B12 and folinic acid and asked to abstain from smoking and alcohol consumption. His left eye vision had improved to premorbid vision but there no improvement on the right eye. As a conclusion, tobacco-alcohol optic neuropathy is a diagnosis of exclusion and treatment shows variable response.

Keywords: alcohol, methanol, nutritional, tobacco, vitamin B12 deficiency

Correspondence: YNg Tuck Chun, MD (UNIMAS), Department of Ophthalmology, Miri General Hospital, Jalan Cahaya, 98000 Miri, Sarawak, Malaysia.

E-mail: ntchun90@gmail.com 


\section{Neuropati optik tembakau-alkohol selepas pesta arak}

\section{Abstrak}

Laporan kes ini bertujuan untuk membincangkan kes neuropati tembakaualkohol optik akibat penyalahgunaan alkohol dan merokok secara kronik pada seorang lelaki berusia 43 tahun. Laporan kes ini turut membincangkan tentang kemungkinan penyebabnya termasuk kekurangan vitamin B12, keracunan metanol, dan sianida dalam tembakau. Pemeriksaan klinikal dan kajian makmal ke atas darah menyokong diagnosa kekurangan vitamin B12, yang mungkin dimangkinkan lagi oleh metanol dan sianida. Pesakit dirawat dengan vitamin B12 dan asid folinik dan disarankan untuk berhenti merokok dan minum alkohol. Rawatan ini Berjaya memulihkan penglihatan mata kirinya seperti sediakala tetapi tiada peningkatan penglihatan pada mata kanan. Sebagai kesimpulan, diagnosa neuropati optik tembakau-alkohol adalah dibuat secara pengecualian dari kemungkinan penyebab lain. Rawatan juga menunjukkan tindak balas yang pelbagai.

Kata kunci: alkohol, kekurangan vitamin B12, metanol, nutrisi, tembakau

\section{Introduction}

Tobacco-alcohol optic neuropathy is caused by toxic exposure and vitamin deficiency. Chronic smokers and drinkers are exposed to toxic substances that can compromise the vascular supply of the optic nerve. Nutritional deficiency acquired after chronic exposure to alcohol and tobacco might aggravate optic neuropathy. It is a disease often diagnosed late, when recovery of vision is not always possible. ${ }^{1,2}$ This case presents a patient who was diagnosed early with tobacco-alcohol optic neuropathy after excluding other more common causes of optic neuropathy. Treatment was started but visual improvement was seen only in one eye with no visual improvement in the contralateral eye.

\section{Case report}

A 43-year-old man who was an active chronic smoker (40 cigarettes per day for the past 26 years) with no known medical illness presented with sudden onset of bilateral blurring of vision for 1 day. He had been a consuming alcohol regularly for 20 years ( 5 units per week), with episodes of binge drinking in the last 2 months, 
when he drank 10 units of alcohol in each session almost daily. On presentation, visual acuity was counting fingers for the right eye and 6/36 for the left eye. Optic nerve function in both eyes was reduced, with peripheral field loss and right eye central scotoma. Fundus examination showed bilateral pink but swollen optic discs (Fig. 1).

Contrasted computerized tomography of the brain and orbit were unremarkable, without abnormal enhancement. His peripheral blood film revealed mixed normochromic normocytic and macrocytic red cells. Haemoglobin level was $5.9 \mathrm{~g} / \mathrm{dL}$. His erythrocyte sedimentation rate was raised $(41 \mathrm{~mm} / \mathrm{hr})$. Platelet and coagulation profiles were normal. He was initially treated as megaloblastic anaemia. Intramuscular injection of vitamin B was initiated, but there was only minimal visual recovery in the left eye and no improvement in the right eye. His pre-treatment serum vitamin B12 and folate level were later revealed to be normal.

With the advice of abstaining from alcohol and smoking, two weeks later vision in the left eye improved to 6/9, while right eye still showed no improvement. In addition, his optic disc appeared to be less swollen but had turned pale (Fig. 2). Our final diagnosis was bilateral tobacco-alcohol optic neuropathy. Four months later, his vision remained unchanged and the haemoglobin level improved to $9.2 \mathrm{~g} / \mathrm{dL}$.

\section{Discussion}

Nutritional and toxic optic neuropathies (NTON) represent a group of medical disorders defined by visual disturbances due to optic nerve damage caused by nutritional deficit or toxins. The most common form of NTON is related to the chronic use of alcohol in heavy smokers, known as tobacco-alcohol optic neuropathy. ${ }^{2}$

The mechanism of tobacco-alcohol optic neuropathy remains unclear. However, in animal studies, toxic substances such as methanol show a predilection for the optic nerve. Methanol is an adulterant in illegally produced alcoholic beverages and accumulation of its metabolite, formic acid, can cause the optic disc to become hyperaemic with oedema, followed by optic atrophy, which was seen in this case. ${ }^{2,3}$ Other toxic substances chronic smokers and drinkers are exposed to include tobacco, lead, cyanide, and ethanol, which can compromise the vascular supply of the optic nerve and subsequently impair mitochondrial function. Cyanide is present only in small amounts in cigarettes; smoking alone, even in large quantities, rarely causes optic neuropathy. Optic neuropathy normally occurs in malnourished smokers who are also consuming excessive amounts of alcohol., ${ }^{2,4}$ Vitamin B12 and folate deficiency acquired from food deprivation after chronic exposure to alcohol and tobacco might trigger or worsen optic neuropathy. ${ }^{1,2}$

Tobacco-alcohol optic neuropathy is a diagnosis of exclusion and a detailed history and ocular examination including colour vision, visual field test, and investigations for serum B12 and folate levels are essential for diagnosis. Neuroimag- 


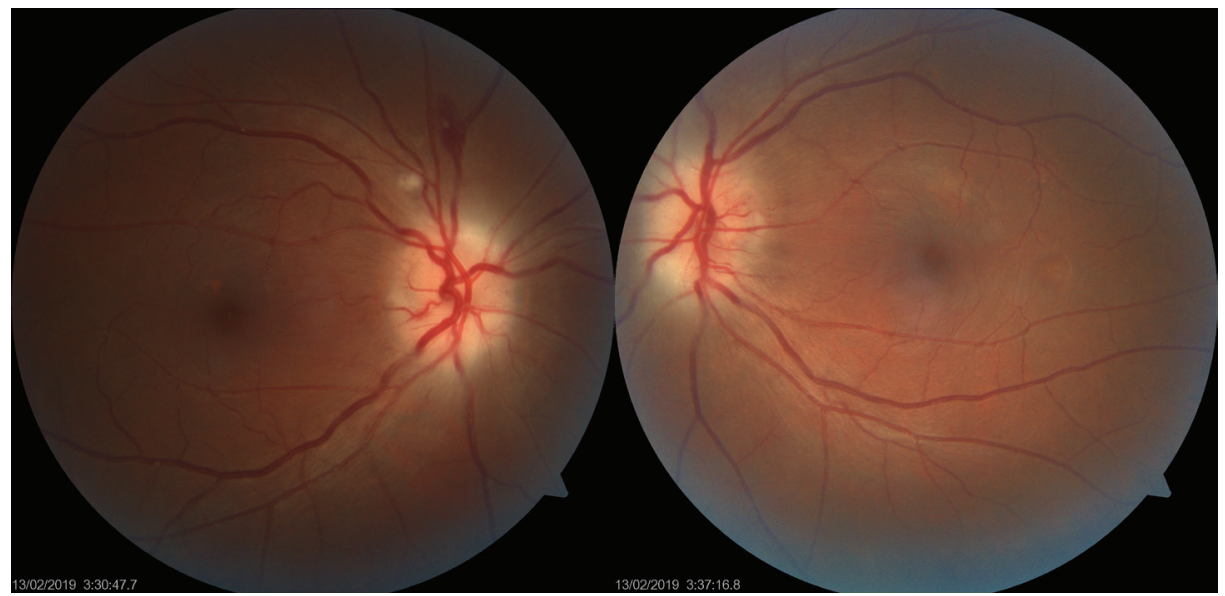

Fig. 1. Fundus images of the right eye (left) and left eye (right) taken on initial presentation showing bilateral swollen optic discs..

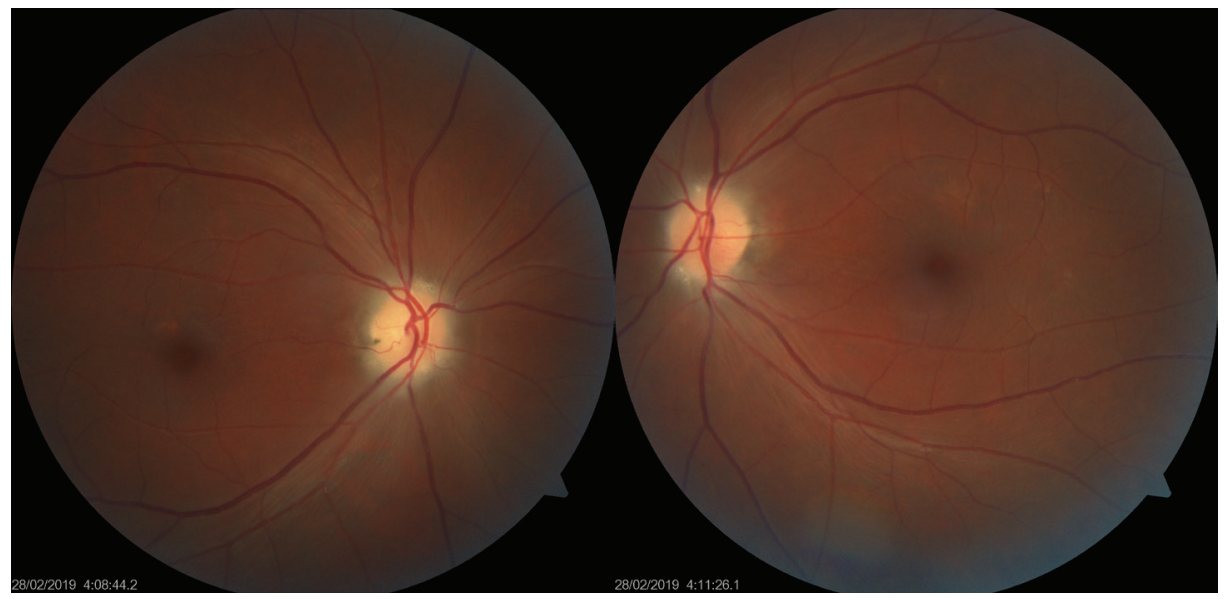

Fig. 2. Fundus images of the right eye (left) and left eye (right) taken 2 weeks after treatment showing less swollen but pale optic discs.

ing is usually normal but is indicated to rule out a space-occupying lesion causing papilloedema and compressive neuropathy. ${ }^{1}$ With relation to this case, both eyes showed reduced optic nerve function and the right eye showed a central scotoma, which is a feature of tobacco-alcohol optic neuropathy. Neuroimaging was normal and blood film showed mixed normocytic and macrocytic anaemia with normal vitamin B12 and folate levels.

Vitamin B12 and folate levels are late, relatively insensitive, and unspecific biomarkers of deficiency. 5 Even with normal levels of vitamin B12 and folate, 
deficiency is still possible. ${ }^{5}$ Increased serum formate levels is a sensitive and specific way to diagnose methanol poisoning, but it was not performed in this patient due to lack of resources. ${ }^{6}$ Blood gas will show metabolic acidosis in cases of methanol poisoning but was not done in this case.

The initial treatment of tobacco-optic neuropathy is based on the suspected toxic agent or nutritional deficiency, coupled with abstaining from tobacco and alcohol. Treatment of vitamin B12 deficiency involves administrating intramuscular cyanocobalamin. The patient was given intramuscular cyanocobalamin $1 \mathrm{mg}$ daily for 1 week and then weekly for 10 weeks with full blood count monitoring. For cases of methanol poisoning, treatment includes administration of alcohol dehydrogenase inhibitor (fomeprizole or ethanol) and folinic acid supplementation, which prevent formation of its toxic metabolite and accelerate the metabolism of formic acid, respectively. ${ }^{3}$ Alcohol dehydrogenase inhibitor was not given to this patient as he was not showing symptoms of significant acidaemia; however, he was supplemented with folinic acid. Treatment for cyanide poisoning involves administration of parenteral hydroxycobalamin, which chelates cyanide to form cyanocobalamin. ${ }^{2}$ The patient was given intramuscular cyanocobalaminn to treat the vitamin B12 deficiency; he did, however, show signs of improvement possibly because of hydroxycobalamin content as high as $30 \%$ were found in a vial of cyanocobalamin due to manufacture impurity and action of photolysis. ${ }^{4}$

Tobacco-alcohol optic neuropathy has a variable prognosis and depends on the toxic agent involved, degree of exposure, and visual acuity at presentation. ${ }^{2}$ In a retrospective case series describing visual outcomes of 37 patients, $62 \%$ of patients had complete recovery, $14 \%$ had partial recovery, $14 \%$ had complete blindness, and $10 \%$ had initial partial recovery followed by deterioration and complete blindness. ${ }^{7}$ In this case, the visual recovery was variable for each eye of the same patient despite treatment.

\section{Conclusion}

Tobacco-alcohol optic neuropathy is an important cause of optic neuropathy and a diagnosis of exclusion. In presence of a bilateral optic disc swelling with suggestive history and normal imaging of the brain, patients should be initiated with vitamin B12 supplements, folinic acid, and advised to abstain from the likely source of the toxic substance.

\section{References}

1. Sharma R, Sharma P. Toxic optic neuropathy. Indian J Ophthalmol. 2011;59(2):137-141. 
2. Chiotoroiu S, Noaghi M, Stefaniu G, Secureanu F, Purcarea V, Zemba M. Tobacco-alcohol optic neuropathy - clinical challenges in diagnosis. J Med Life. 2014;7(4):472-476.

3. Ranche J, Cruz R, Inocencio F. Methanol-induced bilateral optic neuropathy. Philipp J Ophthalmol. 2004;29(4):189-192.

4. Freeman A. Optic Neuropathy and Chronic Cyanide Intoxication: A Review. J R Soc Med. 1988;81(2):103-106.

5. Herrmann W, Obeid R. Causes and Early Diagnosis of Vitamin B12 Deficiency. Dtsch Arztebl Int. 2008;105(40):680-685.

6. Hovda K, Urdal P, Jacobsen D. Increased Serum Formate in the Diagnosis of Methanol Poisoning. J Anal Toxicol. 2005;29(6):586-588.

7. Sanaei-Zadeh H, Zamani N, Shadnia S. Outcomes of visual disturbances after methanol poisoning. Clin Toxicol(Phila). 2011;49(2):102-107. 